\title{
Increased survival of cirrhotic patients with septic shock
}

\author{
Bertrand Sauneuf ${ }^{1}$, Benoit Champigneulle ${ }^{1}$, Alexis Soummer ${ }^{1,2}$, Nicolas Mongardon ${ }^{1,2}$, Julien Charpentier ${ }^{1}$, \\ Alain Cariou ${ }^{1,2,3}$, Jean-Daniel Chiche ${ }^{1,2,4}$, Vincent Mallet ${ }^{2,4,5}$, Jean-Paul Mira ${ }^{1,2,4}$ and Frédéric Pène $e^{1,2,4^{*}}$
}

\begin{abstract}
Introduction: The overall outcome of septic shock has been recently improved. We sought to determine whether this survival gain extends to the high-risk subgroup of patients with cirrhosis.

Methods: Cirrhotic patients with septic shock admitted to a medical intensive care unit (ICU) during two consecutive periods (1997-2004 and 2005-2010) were retrospectively studied.

Results: Forty-seven and 42 cirrhotic patients presented with septic shock in 1997-2004 and 2005-2010, respectively. The recent period differed from the previous one by implementation of adjuvant treatments of septic shock including albumin infusion as fluid volume therapy, low-dose glucocorticoids, and intensive insulin therapy. ICU and hospital survival markedly improved over time (40\% in $2005-2010$ vs. $17 \%$ in $1997-2004, P=0.02$ and $29 \%$ in $2005-2010$ vs. $6 \%$ in $1997-2004, P=0.009$, respectively). Furthermore, this survival gain in the latter period was sustained for 6 months (survival rate $24 \%$ in $2005-2010$ vs. $6 \%$ in 1997-2004, $P=0.06$ ). After adjustment with age, the liver disease stage (Child-Pugh score), and the critical illness severity score (SOFA score), ICU admission between 2005 and 2010 remained an independent favorable prognostic factor (odds ratio (OR) 0.09, 95\% confidence interval $(\mathrm{Cl}) 0.02-0.4, P=0.004)$. The stage of the underlying liver disease was also independently associated with hospital mortality (Child-Pugh score: OR 1.42 per point, 95\% Cl 1.06-1.9, $P=0.018$ ).
\end{abstract}

Conclusions: In the light of advances in management of both cirrhosis and septic shock, survival of such patients substantially increased over recent years. The stage of the underlying liver disease and the related therapeutic options should be included in the decision-making process for ICU admission.

\section{Introduction}

The overall incidence of severe sepsis and septic shock is steadily increasing due to the aging of the population and to the growing prevalence of underlying co-morbidities including chronic organ dysfunctions and immunosuppression $[1,2]$. Several studies have highlighted the major influence of cirrhosis on the susceptibility to severe bacterial infections [3,4]. Indeed, the overall mortality rate of septic shock remains particularly high in cirrhotic patients, ranging from $60 \%$ to $100 \%$ [5-7], raising the question of indications of aggressive and extensive organ failure support in such patients.

\footnotetext{
* Correspondence: frederic.pene@cch.aphp.fr

${ }^{1}$ Medical intensive care unit, Cochin Hospital, Hôpitaux Universitaires Paris Centre, Assistance Publique des Hôpitaux de Paris, 27 rue du Faubourg Saint-Jacques, 75014 Paris, France

Full list of author information is available at the end of the article
}

The overall outcome of septic shock has clearly improved over the recent years, related to improved supportive care and rapid and protocolized treatment interventions supported by international guidelines [8]. Of note, the most significant improvements in survival from septic shock have been achieved in vulnerable subgroups including elderly patients, those with malignancies $[9,10]$ or neutropenia [11]. Cirrhotic patients are usually excluded from interventional trials in sepsis, but it is likely that such a high-mortality subgroup would particularly benefit from therapeutic advances in septic shock. In addition, great strides have also been recently achieved in the management of specific complications of cirrhosis. Whether the survival gain achieved by therapeutic advances in septic shock also extends to cirrhotic patients has not been assessed. In order to determine the trend in mortality of cirrhotic patients with septic shock and the impact of related therapeutic interventions, we performed
C Biomed Central

(c) 2013 Sauneuf et al.; licensee BioMed Central Ltd. This is an open access article distributed under the terms of the Creative Commons Attribution License (http://creativecommons.org/licenses/by/2.0), which permits unrestricted use, distribution, and reproduction in any medium, provided the original work is properly cited. 
a retrospective single-center study over a 14-year time period.

\section{Materials and methods Patients and setting}

The study took place in a 24-bed medical ICU with an average of 1,500 admissions per year. All patients with histological or clinical diagnosis of cirrhosis and presenting with septic shock at the time of ICU admission or within the first $48 \mathrm{~h}$ in the ICU were included. Septic shock was defined as a microbiologically proven or clinically suspected infection, associated with acute circulatory failure requiring vasoactive support despite adequate fluid filling [12]. Senior staffing remained quite stable over the 14-year study period. ICU admission decisions were taken on by both the intensivist and the referring hepatologist throughout the study period. Therefore, only patients with end-stage liver disease declined for liver transplantation were not admitted to the ICU. End-of-life decisions to withhold or withdraw life support were taken on collectively when all participants were convinced that maintenance or increase of life-sustaining therapies was futile and that death would irremediably occur in a short-term manner.

Informed consent was waived since the study was retrospective and observational, in accordance with French regulation of clinical research. This epidemiologic study did not require ethical approval, in accordance with the standards of our local institutional review board.

\section{Intended care for cirrhotic patients with septic shock}

Systematic screening for infection included clinical features (temperature, signs of shock), biological parameters (leukocytes), chest X-rays, and cultures of blood, sputum, urine, and ascites. As soon as infection was recognized, patients were promptly treated with empirical broad-spectrum antibiotic combination, depending on the site of infection, known colonization and previous antibiotic treatment. Antifungal therapy was added if fungal infection was suspected or documented. Antimicrobial treatment was narrowed after identification of the responsible pathogen. In addition, source control measures, such as surgery or removal of infected catheters were applied when necessary. Hemodynamic management included fluid resuscitation combined with continuous infusion of vasoactive drugs (mostly norepinephrin, while associated cardiac dysfunction prompted the use of either a combination of norepinephrin and dobutamine or epinephrin). Terlipressin was not used in combination with other vasoactive drugs. Endotracheal intubation and mechanical ventilation were performed in case of respiratory failure or coma. Renal replacement therapy (RRT), through either intermittent hemodialysis or continuous venovenous hemofiltration was initiated in case of acute renal failure, severe metabolic acidosis, or other life-threatening metabolic disorders.

Several adjuvant therapies were progressively implemented in septic patients over the study period. Thus, patients with acute respiratory distress syndrome (ARDS) were mechanically ventilated using a protective strategy with low tidal volume of $6 \mathrm{~mL} / \mathrm{kg}$ of predicted body weight [13]. More generally, the plateau pressure was limited to $30 \mathrm{~cm} \mathrm{H}_{2} \mathrm{O}$ in all ventilated patients. Intensive insulin therapy was used to maintain blood glucose between 4.4 and $8.1 \mathrm{mmol} / \mathrm{L}$ [14]. Low-dose corticosteroids (200 mg hydrocortisone per day) were administrated in vasopressor-dependent septic shock for 5 to 7 days [15]. Patients with at least two organ dysfunctions were considered for treatment with activated protein $C$ in the absence of contraindication [16]. In order to assess whether these therapeutic advances resulted in improved survival in cirrhotic septic patients, we divided the whole cohort in two near-sized period groups, 1997-2004 (first period) and 2005-2010 (second period), in between the first guidelines of the Surviving Sepsis Campaign were published.

\section{Data collection}

The following data were collected: demographic characteristics; Charlson co-morbidity index (excluding points for liver disease) [17]; functional status prior to ICU admission as assessed by the Knaus scale (A, prior good health, no functional limitation; $B$, mild to moderate limitation of activity because of a chronic disease; $\mathrm{C}$, serious but not incapacitating restriction of activity; D, severe restriction of activity, including bedridden or institutionalized persons) [18]; stage of cirrhosis graded using the Child-Pugh classification [19]; and the Model for End-stage Liver Disease (MELD) score [20]. ChildPugh score was computed prior to the current acute complication whereas MELD score was computed on the first day in the ICU. We also collected the infection characteristics including microbiological and clinical documentation and adequacy of initial antibiotic regimen within the early $48 \mathrm{~h}$ following the onset of infection, the organ failures supports including type and volume of fluid loading, mechanical ventilation and RRT, as well as adjuvant treatments of sepsis (intensive insulin therapy, low-dose glucocorticoids and activated protein C). The Simplified Acute Physiology Score 2 (SAPS II) and the Sequential Organ Failure Assessment (SOFA) score were calculated on the first day in the ICU [21,22]. Outcomes were in-ICU, in-hospital, and 6month survival rates. Vital status was assessed using the medical records or the administrative hospital database. The outcome of patients followed up in another hospital or discharged home was requested to their referring hepatologist or their general practitioner. 


\section{Statistical analysis}

Results are reported as median (25th-75th percentile) or number (\%) as appropriate. Categorical variables were compared with $\chi^{2}$ or Fisher exact tests, and continuous variables were compared with the Mann-Whitney U test. Survival curves were obtained using the Kaplan-Meier method and compared using the log-rank test. To identify characteristics associated with hospital mortality, we used a logistic regression model. Variables that reached a $P$ value $<0.1$ were entered into a multivariate analysis. Inclusion of severity scores in the analysis precluded the inclusion of related variables in order to avoid colinearity. The goodness-of-fit of the model was evaluated by the Hosmer-Lemeshow statistic. Odds ratios (OR) and their 95\% confidence intervals (CI) were computed. All test were two-sided and $P$ values $<0.05$ were considered statistically significant. All calculations were performed with SPSS software version 16 (SPSS, Chicago, IL, USA).

\section{Results}

\section{Patients characteristics}

During the 14-year study period, 1,632 patients with septic shock were admitted to the ICU, including 89 patients (5.5\%) with cirrhosis. Among them, 47 patients were admitted to the ICU during the first period (1997-2004) whereas 42 were admitted during the latter (2005-2010) (Figure 1). Underlying characteristics of patients are presented in Table 1 and were grossly similar between both study periods. Most cirrhosis was caused by chronic alcohol abuse associated or not with chronic viral hepatitis $B$ or $\mathrm{C}$ infection. None of the patients presented with acute alcoholic hepatitis. Six patients had hepatocellular carcinoma, at an early stage (stage $\mathrm{A}, n=2$ ) or at an intermediate stage (stage $\mathrm{B}, n=4)$, according to the BCLC classification [23].

The main sites of infections were pneumonia (42\%), spontaneous or secondary peritonitis (29\%), and urinary tract infection (11\%). Sixty-nine patients (78\%) had microbiologically documented infections balanced between gram-positive cocci (31\%) and gram-negative bacilli (31\%) (Table 1). Multi-drug resistant bacteria were more frequently involved in the recent period (Table 1).

\section{Management of organ failures}

Major differences were noted in the management of septic shock between both study periods, including type and volumes of fluid loading within the first 3 days, ventilatory management, and adjuvant therapies of sepsis

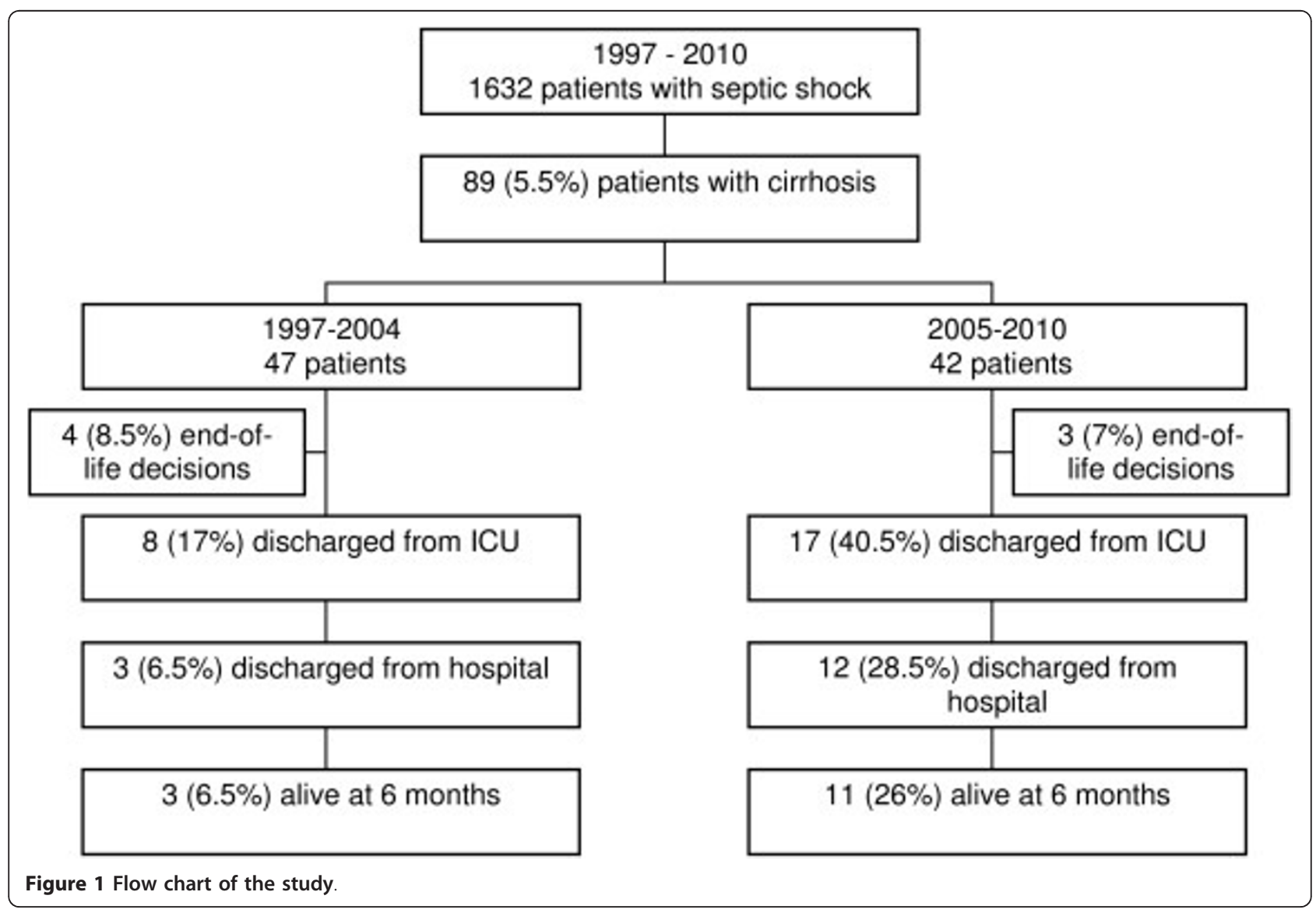


Table 1 Baseline characteristics of patients.

\begin{tabular}{|c|c|c|c|}
\hline Characteristic & $\begin{array}{l}1997-2004 \\
47 \text { patients }\end{array}$ & $\begin{array}{l}2005-2010 \\
42 \text { patients }\end{array}$ & $P$ \\
\hline Age (years, IQR) & $55(46.5-62)$ & $58(53-65)$ & 0.08 \\
\hline Male gender & $36(76.5)$ & $26(62)$ & 0.49 \\
\hline Knaus scale & & & 0.15 \\
\hline Mild limitation (B) & $6(12.8)$ & $10(23.8)$ & \\
\hline Important limitation (C) & $25(53.2)$ & $17(40.5)$ & \\
\hline Severe limitation (D) & $16(34)$ & $15(35.7)$ & \\
\hline$\overline{\text { Charlson score }(\mathrm{IQR})^{\mathrm{a}}}$ & $1(0-1)$ & $1(0-2)$ & 0.51 \\
\hline \multicolumn{4}{|l|}{ Co-morbidities } \\
\hline Chronic heart failure & $4(8.5)$ & $3(7)$ & 0.81 \\
\hline COPD & $2(4.3)$ & $3(7)$ & 0.79 \\
\hline Diabetes & $6(12.8)$ & $10(24)$ & 0.27 \\
\hline Cancer & $8(17)$ & $8(19)$ & 0.80 \\
\hline Hepatocellular carcinoma & 3 & 3 & \\
\hline Other $^{\mathrm{b}}$ & 5 & 5 & \\
\hline Immunosuppression $^{c}$ & $6(12.8)$ & $2(4.8)$ & 0.27 \\
\hline \multicolumn{4}{|l|}{ Cause of cirrhosis $^{d}$} \\
\hline Alcohol +/- virus & $38(80.1)$ & $34(80.1)$ & 1 \\
\hline Chronic Hepatitis B virus infection & $2(4.3)$ & 0 & 0.50 \\
\hline Chronic Hepatitis C virus infection & $6(12.8)$ & $4(9.5)$ & 0.74 \\
\hline Primary biliary cirrhosis & $2(4.3)$ & $2(4.8)$ & 1 \\
\hline Undetermined & $3(6.4)$ & $2(4.8)$ & 1 \\
\hline Persistent alcohol abuse & $26(55.3)$ & $22(52.3)$ & 0.83 \\
\hline Nosocomial septic shock & $13(27.7)$ & $14(33.3)$ & 0.67 \\
\hline \multicolumn{4}{|l|}{ Primary source of infection } \\
\hline Respiratory & $18(38.3)$ & $19(45.2)$ & 0.53 \\
\hline Abdominal & $10(21.3)$ & $16(38,1)$ & 0.10 \\
\hline Spontaneous peritonitis & $8(17)$ & $14(33.3)$ & \\
\hline Secondary peritonitis & $2(4.3)$ & $2(4.8)$ & \\
\hline Urinary tract & $6(12.8)$ & $4(9.5)$ & 0.49 \\
\hline \multicolumn{4}{|l|}{ Others } \\
\hline CNS & $3(6.4)$ & 0 & 0.10 \\
\hline Arthritis & $1(2.1)$ & $1(2.4)$ & 1 \\
\hline Isolated bacteriemia & $2(4.2)$ & 0 & 0.50 \\
\hline Unknown & $7(14.9)$ & $2(4.8)$ & 0.16 \\
\hline Bacteremia & $20(42.6)$ & $14(33.3)$ & 0.39 \\
\hline \multicolumn{4}{|l|}{ Type of organisms } \\
\hline Gram-positive cocci & 15 (31.9) & $13(30.9)$ & 1 \\
\hline Gram-negative bacilli & $17(36.2)$ & $11(23.8)$ & 0.25 \\
\hline Fungi & $2(4.3)$ & $2(4.8)$ & 1 \\
\hline Culture negative & $12(25.5)$ & $8(19)$ & 0.61 \\
\hline Polymicrobial sepsis & $1(2.1)$ & $8(19)$ & 0.01 \\
\hline Multi-drug resistant bacteria & $2(4.3)$ & $8(17)$ & 0.04 \\
\hline
\end{tabular}

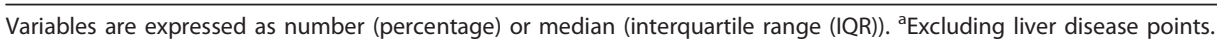

${ }^{b}$ Breast cancer $(n=3)$, colon cancer $(n=2)$, laryngeal cancer $(n=2)$, cholangiocarcinoma $(n=1)$, bladder cancer $(n=1)$, myeloma $(n=1)$.

Infection by human immunodeficiency virus $(n=2)$, multiple myeloma $(n=1)$, hypogammaglobulinemia $(n=1)$, treatment with mesalazine $(n=1)$ and recent chemotherapy for cancer $(n=3)$.

${ }^{\mathrm{d}}$ Sum of causes may exceed the number of patients because of concomitant alcoholic and viral cirrhosis.

CNS, Central Nervous System; COPD, Chronic Pulmonary Obstructive Disease. 
(Table 2). Indeed, intravenous albumin was frequently used in the most recent period $(57.1 \%$ of patients $v s .8 .5 \%$, $P<0.001)$ whereas infusion of crystalloids was markedly reduced in the same time $(3$ (1.7-4.5) L vs. $6(3-8.9) \mathrm{L}, P<$ $0.001)$. Moreover, albumin-resuscitated patients tended to receive a higher albumin dose during the recent period (50 (30-72.5) vs. 20 (17.5-30) g, $P=0.06)$. RRT was less frequently required in the recent period (52.4vs. 72.3\%, $P=0.08$ ). The ventilatory management also significantly differed between the two periods with smaller tidal volumes used in the period 2005-2010 $(8.6 v s .7 \mathrm{~mL} / \mathrm{kg}$, $P=0.001)$. Intensive insulin therapy and low-dose glucocorticoids were also more frequently used in the second period $(83.3 \%$ vs. $31.9 \%, P<0.001$ and $81 \%$ vs. 44.7 ,

Table 2 Organ failures, ICU management, and outcome.

\begin{tabular}{|c|c|c|c|}
\hline Characteristic & $\begin{array}{l}1997-2004 \\
47 \text { patients }\end{array}$ & $\begin{array}{l}2005-2010 \\
42 \text { patients }\end{array}$ & $P$ \\
\hline \multicolumn{4}{|l|}{ Scoring systems (IQR) } \\
\hline Child-Pugh score & $9(7-11)$ & $10(8.25-11)$ & 0.22 \\
\hline MELD day 1 & $25(17-33.8)$ & $26(20.2-32.8)$ & 0.43 \\
\hline SAPS $\|$ day 1 & $56(38-70.5)$ & $59(42-76)$ & 0.10 \\
\hline SOFA day 1 & $14(8.5-17.5)$ & $13(9-15)$ & 0.18 \\
\hline \multicolumn{4}{|l|}{ Biological findings at ICU admission (IQR) } \\
\hline Serum creatinine level, $\mu \mathrm{mol} / \mathrm{L}$ & 140 (96-199) & $147(105-235)$ & 0.93 \\
\hline Serum bilirubin level, $\mu \mathrm{mol} / \mathrm{L}$ & $48(35-110)$ & $68(44.2-140.5)$ & 0.23 \\
\hline Arterial blood lactate level, $\mathrm{mmol} / \mathrm{L}$ & $4.2(2-6.5)$ & $4.3(2.2-7.9)$ & 0.68 \\
\hline Serum sodium, mmol/L & $134(130.5-139)$ & $135.5(129.2-139)$ & 0.74 \\
\hline Serum protein level, g/L & $54(44.5-61)$ & $59(50-66.8)$ & 0.05 \\
\hline Factor $V, \%$ & $42(33-64)$ & $46(33-60)$ & 0.70 \\
\hline INR & $2(1.5-2.8)$ & $2(1.6-3.1)$ & 0.69 \\
\hline White blood cells, $10^{3} / \mathrm{mm}^{3}$ & $13.6(6.2-19)$ & $10.7(6.4-15.2)$ & 0.45 \\
\hline C-reactive protein, mg/L & $101(60-167)$ & $75(34-127)$ & 0.24 \\
\hline Mechanical ventilation & $45(95.7)$ & $39(93)$ & 0.34 \\
\hline Tidal volume, mL/kg (IQR) ${ }^{a}$ & $8.6(7.3-9.9)$ & $7(6.1-7.9)$ & $<0.001$ \\
\hline Lowest $\mathrm{PaO}_{2} / \mathrm{FiO}_{2}$ ratio (IQR) & $101(80-150)$ & $117(86-206)$ & 0.17 \\
\hline ARDS & $16(34)$ & $14(33.3)$ & 1 \\
\hline Renal replacement therapy & $34(72.3)$ & $22(52.4)$ & 0.08 \\
\hline \multicolumn{4}{|l|}{ Antimicrobial treatment } \\
\hline$\beta$-lactam & $45(95.7)$ & $41(97.6)$ & 1 \\
\hline Quinolone & $19(40.4)$ & $12(25.5)$ & 0.27 \\
\hline Aminoglycoside & $23(49)$ & $22(52.4)$ & 0.83 \\
\hline Glycopeptide & $9(19.1)$ & $6(14.3)$ & 0.58 \\
\hline Combination therapy & $31(64)$ & $34(81)$ & 0.15 \\
\hline Inadequacy of initial antimicrobial treatment & $5(10.6)$ & $3(7.1)$ & 1 \\
\hline \multicolumn{4}{|l|}{ Fluid loading within the first 3 days } \\
\hline Crystalloids, L (IQR) & $6(3-8.9)$ & $3(1.7-4.5)$ & $<0.001$ \\
\hline Albumin resuscitation & $4(8.5)$ & $24(57.1)$ & $<0.001$ \\
\hline \multicolumn{4}{|l|}{ Adjuvant therapies of sepsis } \\
\hline Intensive insulin therapy & $15(31.9)$ & $35(83.3)$ & $<0.001$ \\
\hline Low-dose glucocorticoids & $21(44.7)$ & $34(81)$ & $<0.001$ \\
\hline Activated protein $C$ & 0 & $2(4.8)$ & 1 \\
\hline ICU survival & $8(17)$ & $17(40)$ & 0.02 \\
\hline Hospital survival & $3(6)$ & $12(29)$ & 0.009 \\
\hline 6-month survival & $3(6)$ & $9(21)$ & 0.06 \\
\hline
\end{tabular}

Variables are expressed as number (percentage) or median (interquartile range (IQR)).

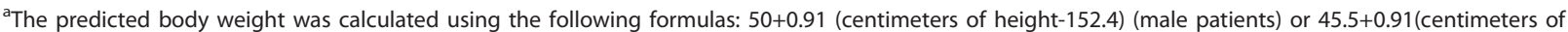
height-152.4) (female patients).

ARDS, Acute Respiratory Distress Syndrome; INR, International Normalized Ratio; MELD, Model for End Stage Liver Disease; SAPS, Simplified Acute Physiology Score; SOFA, Sequential Organ Failure Assessment. 
$P<0.001$, respectively). Only two patients were treated with drotrecogin alpha (activated) in the recent period.

\section{Short-term and long-term outcomes}

The rate of end-of-life decisions was similar between the two periods (Figure 1). The 6-month vital status was obtained for all patients. We observed a marked improvement in ICU and hospital survival rates in the recent period as compared to the 1997-2004 period (40\% vs. 17\%, $P=0.02$ and $29 \%$ vs. $6 \%, P=0.009$, respectively). Most importantly, differences in survival occurred early in the course of the disease (Figure 2A). The benefit in shortterm survival was sustained throughout the first 6 months following ICU admission (6-month survival rate $21 \% v s$. $6 \%, P=0.06$ ) (Figure 2B). Two survivors of the recent period underwent liver transplantation within 6 months after ICU admission.

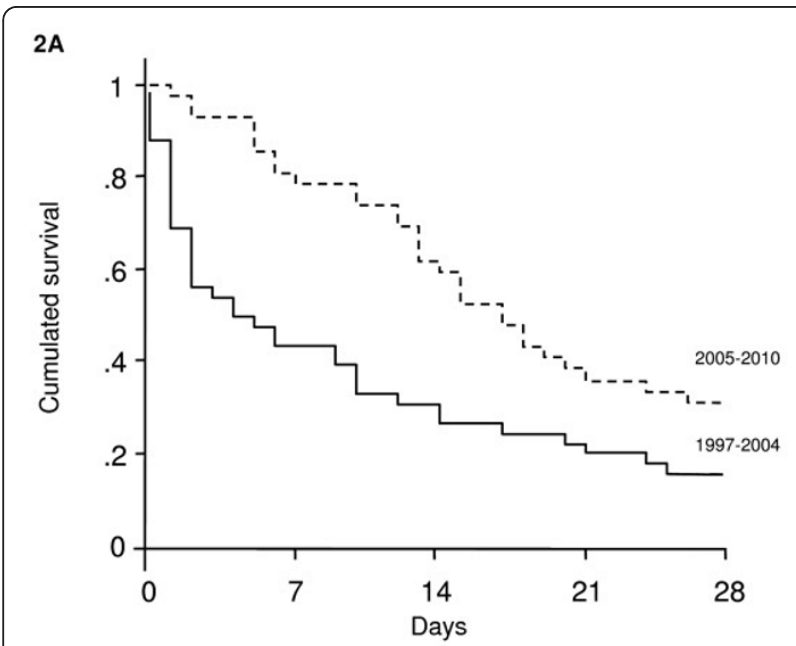

2B

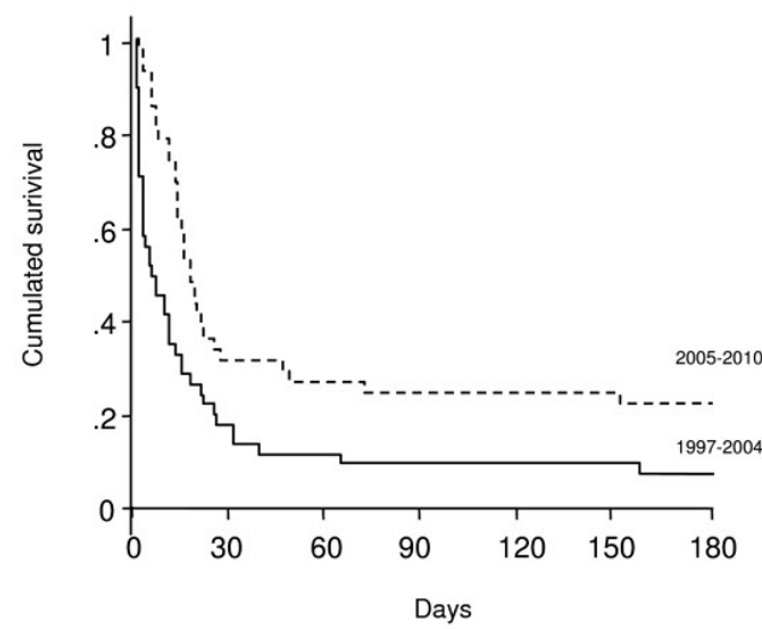

Figure 2 Kaplan Meier estimates of 28-day (A) and 6-month (B) survival according to the period of admission (1997-2004, continuous line; 2005-2010, dotted line). Log-rank test: $P=0.02$.

\section{Prognostic factors of hospital mortality}

In order to identify the determinants of outcome, we compared the characteristics and treatments of hospital survivors and non-survivors (Table 3). Determinants of hospital mortality were the stage of the liver disease (Child-Pugh score, serum protein, and factor V levels), the extent of organ failures (day-1 SAPS II and SOFA scores, admission serum lactate level, renal replacement therapy), and admission during the first period. Finally, we carried out a multivariate logistic regression analysis taking into account the underlying liver disease stage (Child-Pugh score), the critical illness severity score (for example, SOFA score), and the recent changes in sepsis management (ICU admission period). When adjusted for admission SOFA score and age, the 2005-2010 period remained protective (OR 0.09, 95\% CI 0.02-0.4) whereas the stage of cirrhosis prior to the acute complication was independently associated with hospital mortality (Child-Pugh score: OR 1.42 per point, 95\% CI 1.06-1.9) (Table 4). Similar results were obtained when adjusted for SAPS II.

\section{Discussion}

Septic shock represents a severe complication of cirrhosis with very low survival rates that question the relevance of life-sustaining therapies in this subgroup of patients. We

Table 3 Determinants of hospital outcome (univariate analysis).

\begin{tabular}{|c|c|c|c|}
\hline Variable & $\begin{array}{l}\text { Deceased } \\
74 \text { patients }\end{array}$ & $\begin{array}{l}\text { Survivors } \\
15 \text { patients }\end{array}$ & $P$ \\
\hline Age (IQR) & $56(48-65)$ & $58(54-62.5)$ & 0.6 \\
\hline \multicolumn{4}{|l|}{ Scoring systems (IQR) } \\
\hline Child-Pugh score & $10(8-11)$ & $7(7-10)$ & 0.05 \\
\hline MELD day 1 & $25(18-33.5)$ & $26(18.5-33.5)$ & 0.19 \\
\hline SAPS $\|$ day 1 & $59(41.5-83)$ & $50(42-62.5)$ & 0.02 \\
\hline SOFA day 1 & $14(10-17)$ & $9(7.5-9)$ & 0.03 \\
\hline \multicolumn{4}{|l|}{$\begin{array}{l}\text { Biological findings at ICU } \\
\text { admission (IQR) }\end{array}$} \\
\hline $\begin{array}{l}\text { Arterial blood lactate level, } \\
\mathrm{mmol} / \mathrm{l}\end{array}$ & $4.2(2.1-7.3)$ & $2.8(2-4.5)$ & 0.08 \\
\hline Serum protein level, g/L & $54(45-62)$ & $62.5(56-66)$ & 0.06 \\
\hline Factor $\vee, \%$ & $41(27.5-62.5)$ & $53(48.5-70.5)$ & 0.02 \\
\hline Renal replacement therapy & $40(65 \%)$ & $5(36 \%)$ & 0.02 \\
\hline ARDS & $22(35.5 \%)$ & $2(13.5 \%)$ & 0.08 \\
\hline Albumin resuscitation & $24(32.4)$ & $4(26.7)$ & 0.77 \\
\hline Low-dose glucocorticoids & $44(59.5)$ & $11(73.3)$ & 0.39 \\
\hline Intensive insulin therapy & $39(52.7)$ & $11(73.3)$ & 0.16 \\
\hline \multicolumn{4}{|l|}{ Admission period } \\
\hline 1997-2004 & $44(59.5)$ & $3(20)$ & 0.009 \\
\hline 2005-2010 & $30(40.5)$ & $12(80)$ & \\
\hline
\end{tabular}

Variables are expressed as number (percentage) or median (interquartile range (IQR)).

ARDS, acute respiratory distress syndrome; MELD, Model For End Stage Liver Disease; SAPS, Simplified Acute Physiology Score; SOFA, Sequential Organ Failure Assessment. 
Table 4 Multivariate analysis of factors associated with in-hospital mortality.

\begin{tabular}{lccc}
\hline Variable & Odds ratio & $\mathbf{9 5 \% ~ C l}$ & $\boldsymbol{P}$ \\
\hline SOFA (per point) & 1.15 & $0.99-1.32$ & 0.06 \\
Age & 1.02 & $0.96-1.08$ & 0.53 \\
Child-Pugh score (per point) & 1.42 & $1.06-1.9$ & 0.018 \\
Period 2005-2010 (compared & 0.09 & $0.02-0.4$ & 0.004 \\
to 1997-2004) & & & \\
\hline
\end{tabular}

$\mathrm{Cl}$, confidence interval, Goodness of fit (Hosmer-Lemeshow) chi-square $P$ value $=0.54$

report here that the current survival rate remains low but substantially improved over time, suggesting that advances in care of septic shock extended to this highrisk subgroup of patients. Most importantly, the shortterm improvement in survival was sustained for at least 6 months, suggesting that ICU admission and extensive life support is justified in some patients. In addition to organ failures, the stage of liver disease as assessed by the Child-Pugh score appears to be an independent prognostic factor that should be taken into account in the decision-making process.

Cirrhosis is clearly associated with an increased predisposition to sepsis [4] and has been identified as an independent poor prognostic factor in patients with severe sepsis [24]. In addition, chronic alcohol abuse by itself may contribute to worsening organ failures and has been shown to be an independent risk factor of septic shock [25]. Multiple mechanisms concur to confer an increased susceptibility to bacterial infections and subsequently to multiple organ failure in cirrhotic patients. Bacterial translocation increases with the severity of liver disease and represents the main mechanism of spontaneous bacterial peritonitis. Furthermore, it may sustain the septic process in every type of infection as suggested by the increased levels of endotoxin observed in cirrhotic patients [26]. In addition, innate immune cells display functional abnormalities such as increased production of pro-inflammatory cytokines in response to LPS [27] or alcohol-induced defective phagocytosis [28]. As a consequence, plasma TNF- $\alpha$ and IL- 6 levels are higher in cirrhotic patients with bacterial infection than in non-cirrhotic patients [29].

The overall outcome of severe sepsis and septic shock has been improved over the last decade concomitant to the emergence of adjuvant therapeutic interventions such as early-goal directed therapy [30], protective mechanical ventilation with low tidal volumes [13], low-dose corticosteroids [15], intensive insulin therapy [14], or activated protein $C$ [16] supported by positive randomized controlled trials. Although the true benefit of some of these interventions have been addressed by additional studies, they have been included in the Surviving Sepsis Campaign guidelines [8]. This international guideline-based performance improvement program promoted early recognition and management of sepsis and showed that increased compliance with the guidelines was associated with an improved survival rate [31]. In the same way, a continuous decrease in the mortality of severe sepsis and septic shock patients has been reported in large unselected cohorts that mostly comprised non-cirrhotic patients $[1,32,33]$. Of note, some significant progress in septic shock has also been achieved in highly vulnerable subgroups of patients such as immunocompromised patients with malignancies [9].

Differences in survival between the two periods occurred early in the course of the disorder and were thereafter maintained. The rate of inadequate antibiotic treatment was low and similar between both periods. Most patients received an initial combination antimicrobial treatment of $\beta$-lactam associated with either aminoglycosides or fluoroquinolones. An initial single dose of aminoglycosides was commonly subsequently replaced by fluoroquinolones to limit harmful side-effects. Indeed, some retrospective studies suggest a benefit of combination antibiotherapy, most especially of betalactams and aminoglycosides, for septic shock in general cohorts as well as in cirrhotic patients $[7,34]$. Survival improvement was more likely related to changes in the early management of shock and organ failures. With respect to fluid resuscitation strategies, the majority of patients from the recent period received albumin and consequently received less crystalloids. Albumin resuscitation was associated with higher Child-Pugh and MELD scores $(P=0.04$ and $P=0.03$ respectively, data not shown), suggesting that albumin was preferentially indicated to patients with advanced stages of cirrhosis. The role of albumin resuscitation in sepsis remains challenging. A meta-analysis suggested that fluid resuscitation with albumin compared to crystalloids was associated with improved survival in patients with severe sepsis [35]. Specifically, albumin resuscitation has been shown to reduce mortality and renal impairment in cirrhotic patients treated for spontaneous bacterial peritonitis [36]. Accordingly, frequent albumin resuscitation in the recent period of our study was also associated with less frequent recourse to renal replacement therapy. Altogether, these results and ours suggest a possible benefit of albumin resuscitation in cirrhotic patients with severe sepsis, that remains to be prospectively investigated. The frequent use of low-dose corticosteroids was also a hallmark of sepsis management during the second period. Indeed, adrenal dysfunction frequently occurs in patients with septic shock and is associated with hemodynamic instability, renal dysfunction, and increased mortality [37]. However, the use of lowdose corticosteroids in septic shock remains controversial because of discrepant efficacy data and a possible higher risk of nosocomial infections [15]. Of note, this treatment has been specifically addressed in cirrhotic patients with septic shock. In a case-control study, resolution of shock 
and survival were higher in hydrocortisone-treated cirrhotic patients [38]. However a randomized controlled trial in septic shock cirrhotic patients was stopped for futility at interim analysis because hydrocortisone did not reduce mortality and was associated with an increase in adverse effects such as shock relapse and gastrointestinal bleeding [39]. In addition to sepsis-specific therapies, general measures for ICU patients such as ventilation with low tidal volumes and glucose control with intravenous insulin therapy were also routinely implemented during the second period.

Cirrhotic patients are commonly perceived as poor candidates for ICU admission because of the very high mortality rates associated with organ failures $[40,41]$. A general improvement in outcome for cirrhotic patients in the ICU has been recently reported regardless of the type of acute complication [42,43]. Several factors may explain this progress, including a better selection of patients on the basis of previous functional status and advances in the management of acute complications such as variceal bleeding [44], hepatorenal syndrome [45], or septic shock as highlighted in the present study. The extent of organ failures clearly represents a major determinant of outcome, and the performance of SOFA score that nearly reached significance in our multivariate model is in accordance with previous studies $[6,46]$. Most importantly, we also identified the stage of the underlying liver disease assessed by the Child-Pugh score as an independent prognostic factor of septic shock. Until now, the discrimination of the Child-Pugh score calculated at the time of ICU admission had remained inferior to organ failure scores $[6,46,47]$. As a matter of fact, we computed Child-Pugh score prior to the acute complication in order to reliably assess the stage of liver disease without any interference from new-onset organ failures. This finding carries major practical implications for the decision-making process. Indeed, this could allow a better selection of patients likely to benefit from intensive care, on the basis of underlying disease's status and realistic therapeutic options including liver transplantation. Nevertheless, an accurate individual prognosis prediction of cirrhotic patients is often difficult at the time of ICU admission, but can be markedly refined after a few days $[6,46]$. In the light of improved outcomes and limited performance of initial prognostic prediction, critically-ill cirrhotic patients with a reasonable long-term prognosis should be offered a broad intensive care access policy with subsequent reappraisal based on the nature of the acute complication and the evolution of organ failures.

Our study has several limitations that we acknowledge. First, the design was retrospective despite most data were prospectively collected through computerized patient data management system. Therefore, we can only report an association between changes in care and patient outcome over the study period. Second, it was carried out in a single center, with a hepatology unit that is closely involved in the decision-making process and in the management of critically ill cirrhotic patients while in the ICU and after discharge. Third, the limited number of patients may limit the external validity of our findings. However, our survival rates in the latter period are similar to those reported by Arabi et al. (hospital survival 24\%) [7] and Levesque et al. (ICU survival 36\%) [6]. Fourth, indications for ICU admission or end-of-life decisions might have evolved over the study period, and we cannot exclude that patients from the recent period were more carefully selected or referred earlier to the ICU. Nevertheless, the functional status, the stage of the underlying liver disease and the severity scores were similar between both periods. In addition, arterial blood lactate level as an indicator of prolonged systemic hypoperfusion also suggested similar duration and severity of shock before ICU admission. Altogether, these results suggest that improvements in survival were more likely related to changes in care. Fourth, we failed to link the recent improvement in survival with a single therapeutic change, suggesting that it is more likely related to a combination of interventions. Alternatively, some unrecognized or non-collected data might also influence the outcome. For instance, the functional status assessed by the performance status prior to the acute complication is a major prognostic factor in critically-ill cancer patients [48], and might be more accurate than the Knaus scale in this setting. In the same way, the nutritional status might also be of importance in these patients [49].

\section{Conclusions}

This study reports an encouraging improvement in survival in cirrhotic patients with septic shock that needs to be confirmed in a larger multicenter cohort. Implementation of therapeutic advances in sepsis probably accounted for this result. In addition, the stage of the underlying liver disease appears as an important prognostic factor. Delineation of the long-term prognosis of cirrhosis and the related therapeutic options thus appears essential in order to determine the indications for life-sustaining therapies.

\section{Key messages}

- The current survival rate of septic shock in cirrhotic patients remains low but has improved over the recent years.

- Cirrhotic patients could have benefited from recent advances in the management of septic shock.

- The stage of liver disease prior to the acute complication as assessed by the Child-Pugh score appears to be an independent prognostic factor of hospital mortality. 


\section{List of abbreviations}

ARDS: Acute Respiratory Distress Syndrome; Cl: Confidence Interval; COPD: Chronic Obstructive Pulmonary Disease; ICU: Intensive Care Unit; IL: Interleukin; INR: International Normalized Ratio; MELD: Model for End-stage Liver Disease; OR: Odds Ratio; RRT: Renal Replacement Therapy; SAPS: Simplified Acute Physiology Score; SOFA: Sequential Organ Failure Assessment; TNF: Tumor Necrosis Factor.

\section{Competing interests}

$J C$ is consultant for LFB and received lecture fees. JPM is consultant and member of the scientific board of LFB, and received lecture fees from LFB, Fresenius and Baxter. JC and JPM were the main investigators of an interventional trial on albumin resuscitation in septic shock. FP received lecture fees from LFB. The authors declare that they have no other competing interests relevant to the field of the manuscript.

\section{Authors' contributions}

$\mathrm{BS}, \mathrm{BC}$, and $\mathrm{FP}$ designed the study. BS, BC, AS, and NM extracted the data. $B S$ and FP performed the statistical analysis. BS, BC, AS, NM, JC, AC, JDC, VM, JPM, and FP contributed to data analysis. BS and FP drafted the manuscript. All authors read and approved the final version of the manuscript.

\section{Acknowledgements}

Presented at the 40th Congress of the Société de Réanimation de Langue Française, 18-20 January 2012, Paris, France.

\section{Authors' details}

${ }^{1}$ Medical intensive care unit, Cochin Hospital, Hôpitaux Universitaires Paris Centre, Assistance Publique des Hôpitaux de Paris, 27 rue du Faubourg Saint-Jacques, 75014 Paris, France. ${ }^{2}$ Université Paris Descartes, Sorbonne Paris Cité, Faculté de Médecine, 15 rue de l'école de Médecine, 75014 Paris, France. ${ }^{3}$ INSERM U970, Paris Cardiovascular Research Center (PARCC), European Georges Pompidou Hospital, 56 rue Leblanc, 75015 Paris, France. ${ }^{4}$ Institut Cochin, INSERM U1016, CNRS UMR-8104, 22 rue Méchain, 75014 Paris, France. ${ }^{5}$ Hepatology unit, Cochin Hospital, Hôpitaux Universitaires Paris Centre, Assistance Publique des Hôpitaux de Paris, 27 rue du Faubourg Saint-Jacques, 75014 Paris, France.

Received: 4 November 2012 Revised: 29 January 2013

Accepted: 19 April 2013 Published: 19 April 2013

\section{References}

1. Annane D, Aegerter P, Jars-Guincestre MC, Guidet B: Current epidemiology of septic shock: the CUB-Rea Network. Am J Respir Crit Care Med 2003, 168:165-172.

2. Martin GS, Mannino DM, Eaton S, Moss M: The epidemiology of sepsis in the United States from 1979 through 2000. N Engl J Med 2003, 348:1546-1554.

3. Fernandez J, Navasa M, Gomez J, Colmenero J, Vila J, Arroyo V, Rodes J: Bacterial infections in cirrhosis: epidemiological changes with invasive procedures and norfloxacin prophylaxis. Hepatology 2002, 35:140-148.

4. Foreman MG, Mannino DM, Moss M: Cirrhosis as a risk factor for sepsis and death: analysis of the National Hospital Discharge Survey. Chest 2003, 124:1016-1020

5. Moreau R, Hadengue A, Soupison T, Kirstetter P, Mamzer MF, Vanjak D, Vauquelin P, Assous M, Sicot C: Septic shock in patients with cirrhosis: hemodynamic and metabolic characteristics and intensive care unit outcome. Crit Care Med 1992, 20:746-750.

6. Levesque E, Hoti E, Azoulay D, Ichai P, Habouchi H, Castaing D, Samuel D, Saliba F: Prospective evaluation of the prognostic scores for cirrhotic patients admitted to an intensive care unit. J Hepatol 2011, 56:95-102.

7. Arabi YM, Dara Sl, Memish Z, Al-Abdulkareem A, Tamim HM, Al-Shirawi N, Parrillo JE, Dodek P, Lapinsky S, Feinstein D, Wood G, Dial S, Zanotti S, Kumar A, Cooperative Antimicrobial Therapy of Septic Shock (CATSS) Database Research Group: Antimicrobial therapeutic determinants of outcomes in cirrhotic patients with septic shock. Hepatology 2012, 56:2305-2315.

8. Dellinger RP, Levy MM, Carlet JM, Bion J, Parker MM, Jaeschke R, Reinhart K, Angus DC, Brun-Buisson C, Beale R Calandra T, Dhainaut JF, Gerlach H, Harvey M, Marini JJ, Marshall J, Ranieri M, Ramsay G, Sevransky J, Thompson BT, Townsend S, Vender JS, Zimmerman JL, Vincent JL:
Surviving Sepsis Campaign: international guidelines for management of severe sepsis and septic shock: 2008. Intensive Care Med 2008, 34:17-60.

9. Zuber B, Tran TC, Aegerter P, Grimaldi D, Charpentier J, Guidet B, Mira JP, Pène F: Impact of case volume on survival of septic shock in patients with malignancies. Crit Care Med 2012, 40:55-62.

10. Pène F, Percheron S, Lemiale V, Viallon V, Claessens YE, Marque $S$, Charpentier J, Angus DC, Cariou A, Chiche JD, Mira JP: Temporal changes in management and outcome of septic shock in patients with malignancies in the intensive care unit. Crit Care Med 2008, 36:690-696.

11. Legrand M, Max A, Peigne V, Mariotte E, Canet E, Debrumetz A, Lemiale V, Seguin A, Darmon M, Schlemmer B, Azoulay E: Survival in neutropenic patients with severe sepsis or septic shock*. Crit Care Med 2012, 40:43-49.

12. Levy MM, Fink MP, Marshall JC, Abraham E, Angus D, Cook D, Cohen J, Opal SM, Vincent JL, Ramsay G: 2001 SCCM/ESICM/ACCP/ATS/SIS International Sepsis Definitions Conference. Intensive Care Med 2003, 29:530-538.

13. The Acute Respiratory Distress Syndrom Network: Ventilation with lower tidal volumes as compared with traditional tidal volumes for acute lung injury and the acute respiratory distress syndrome. N Engl J Med 2000, 342:1301-1308

14. van den Berghe G, Wouters P, Weekers F, Verwaest C, Bruyninckx F, Schetz M, Vlasselaers D, Ferdinande $P$, Lauwers $P$, Bouillon R: Intensive insulin therapy in the critically ill patients. N Engl J Med 2001, 345:1359-1367.

15. Annane D, Sebille V, Charpentier C, Bollaert PE, Francois B, Korach JM, Capellier G, Cohen Y, Azoulay E, Troche G, Chaumet-Riffaud P, Bellissant E: Effect of treatment with low doses of hydrocortisone and fludrocortisone on mortality in patients with septic shock. JAMA 2002, 288:862-871

16. Bernard GR, Vincent JL, Laterre PF, LaRosa SP, Dhainaut JF, LopezRodriguez A, Steingrub JS, Garber GE, Helterbrand JD, Ely EW, Fisher CJ Jr: Efficacy and safety of recombinant human activated protein $\mathrm{C}$ for severe sepsis. N Engl J Med 2001, 344:699-709.

17. Charlson ME, Pompei $P$, Ales KL, MacKenzie CR: A new method of classifying prognostic comorbidity in longitudinal studies: development and validation. J Chronic Dis 1987, 40:373-383.

18. Knaus WA, Zimmerman JE, Wagner DP, Draper EA, Lawrence DE: APACHEacute physiology and chronic health evaluation: a physiologically based classification system. Crit Care Med 1981, 9:591-597.

19. Pugh RN, Murray-Lyon IM, Dawson JL, Pietroni MC, Williams R: Transection of the oesophagus for bleeding oesophageal varices. Br J Surg 1973, 60:646-649.

20. Kamath PS, Wiesner RH, Malinchoc M, Kremers W, Therneau TM, Kosberg CL, D'Amico G, Dickson ER, Kim WR: A model to predict survival in patients with end-stage liver disease. Hepatology 2001, 33:464-470.

21. Le Gall JR, Lemeshow S, Saulnier F: A new Simplified Acute Physiology Score (SAPS II) based on a European/North American multicenter study. JAMA 1993, 270:2957-2963.

22. Vincent JL, Moreno R, Takala J, Willatts S, De Mendonca A, Bruining H, Reinhart CK, Suter PM, Thiis LG: The SOFA (Sepsis-related Organ Failure Assessment) score to describe organ dysfunction/failure. On behalf of the Working Group on Sepsis-Related Problems of the European Society of Intensive Care Medicine. Intensive Care Med 1996, 22:707-710.

23. Llovet JM, Bru C, Bruix J: Prognosis of hepatocellular carcinoma: the BCLC staging classification. Semin Liver Dis 1999, 19:329-338.

24. Brun-Buisson C, Meshaka P, Pinton P, Vallet B: EPISEPSIS: a reappraisal of the epidemiology and outcome of severe sepsis in French intensive care units. Intensive Care Med 2004, 30:580-588.

25. O'Brien JM Jr, Lu B, Ali NA, Martin GS, Aberegg SK, Marsh CB, Lemeshow S, Douglas IS: Alcohol dependence is independently associated with sepsis, septic shock, and hospital mortality among adult intensive care unit patients. Crit Care Med 2007, 35:345-350.

26. Lin RS, Lee FY, Lee SD, Tsai YT, Lin HC, Lu RH, Hsu WC, Huang CC, Wang SS, Lo KJ: Endotoxemia in patients with chronic liver diseases: relationship to severity of liver diseases, presence of esophageal varices, and hyperdynamic circulation. J Hepatol 1995, 22:165-172.

27. Deviere J, Content J, Denys C, Vandenbussche P, Schandene L, Wybran J, Dupont $E$ : Excessive in vitro bacterial lipopolysaccharide-induced production of monokines in cirrhosis. Hepatology 1990, 11:628-634.

28. Fiuza C, Salcedo M, Clemente G, Tellado JM: In vivo neutrophil dysfunction in cirrhotic patients with advanced liver disease. J Infect Dis 2000, 182:526-533 
29. Byl B, Roucloux I, Crusiaux A, Dupont E, Deviere J: Tumor necrosis factor alpha and interleukin 6 plasma levels in infected cirrhotic patients. Gastroenterology 1993, 104:1492-1497.

30. Rivers E, Nguyen B, Havstad S, Ressler J, Muzzin A, Knoblich B, Peterson E, Tomlanovich M: Early goal-directed therapy in the treatment of severe sepsis and septic shock. N Engl J Med 2001, 345:1368-1377.

31. Levy MM, Dellinger RP, Townsend SR, Linde-Zwirble WT, Marshall JC, Bion J, Schorr C, Artigas A, Ramsay G, Beale R, Parker MM, Gerlach H, Reinhart K, Silva E, Harvey M, Regan S, Angus DC: The Surviving Sepsis Campaign: results of an international guideline-based performance improvement program targeting severe sepsis. Crit Care Med 2010, 38:367-374.

32. Dombrovskiy WY, Martin AA, Sunderram J, Paz HL: Rapid increase in hospitalization and mortality rates for severe sepsis in the United States: a trend analysis from 1993 to 2003. Crit Care Med 2007, 35:1244-1250.

33. Harrison DA, Welch CA, Eddleston JM: The epidemiology of severe sepsis in England, Wales and Northern Ireland, 1996 to 2004: secondary analysis of a high quality clinical database, the ICNARC Case Mix Programme Database. Crit Care 2006, 10:R42.

34. Kumar A, Zarychanski R, Light B, Parrillo J, Maki D, Simon D, Laporta D, Lapinsky S, Ellis P, Mirzanejad Y, Martinka G, Keenan S, Wood G, Arabi Y, Feinstein D, Kumar A, Dodek P, Kravetsky L, Doucette S, Cooperative Antimicrobial Therapy of Septic Shock (CATSS) Database Research Group: Early combination antibiotic therapy yields improved survival compared with monotherapy in septic shock: a propensity-matched analysis. Crit Care Med 2010, 38:1773-1785.

35. Delaney AP, Dan A, McCaffrey J, Finfer S: The role of albumin as a resuscitation fluid for patients with sepsis: a systematic review and meta-analysis. Crit Care Med 39:386-391.

36. Sort P, Navasa M, Arroyo V, Aldeguer X, Planas R, Ruiz-del-Arbol L, Castells L, Vargas $V$, Soriano $G$, Guevara $M$, Ginès $P$, Rodés J: Effect of intravenous albumin on renal impairment and mortality in patients with cirrhosis and spontaneous bacterial peritonitis. N Engl J Med 1999, 341:403-409.

37. Tsai MH, Peng YS, Chen YC, Liu NJ, Ho YP, Fang JT, Lien JM, Yang C, Chen PC, Wu CS: Adrenal insufficiency in patients with cirrhosis, severe sepsis and septic shock. Hepatology 2006, 43:673-681.

38. Fernandez J, Escorsell A, Zabalza M, Felipe V, Navasa M, Mas A, Lacy AM, Gines $P$, Arroyo V: Adrenal insufficiency in patients with cirrhosis and septic shock: Effect of treatment with hydrocortisone on survival. Hepatology 2006, 44:1288-1295.

39. Arabi YM, Aljumah A, Dabbagh O, Tamim HM, Rishu AH, Al-Abdulkareem A, Knawy BA, Hajeer AH, Tamimi W, Cherfan A: Low-dose hydrocortisone in patients with cirrhosis and septic shock: a randomized controlled trial. CMAJ 2010, 182:1971-1977.

40. du Cheyron D, Bouchet B, Parienti JJ, Ramakers M, Charbonneau P: The attributable mortality of acute renal failure in critically ill patients with liver cirrhosis. Intensive Care Med 2005, 31:1693-1699.

41. Goldfarb G, Nouel O, Poynard T, Rueff B: Efficiency of respiratory assistance in cirrhotic patients with liver failure. Intensive Care Med 1983 9:271-273.

42. O'Brien AJ, Welch CA, Singer M, Harrison DA: Prevalence and outcome of cirrhosis patients admitted to UK intensive care: a comparison against dialysis-dependent chronic renal failure patients. Intensive Care Med 2012, 38:991-1000.

43. Galbois A, Trompette ML, Das V, Boelle PY, Carbonell N, Thabut D, Housset C, Ait-Oufella H, Offenstadt G, Maury E, Guidet B: Improvement in the prognosis of cirrhotic patients admitted to an intensive care unit, a retrospective study. Eur J Gastroenterol Hepatol 2012, 24:897-904.

44. Carbonell N, Pauwels A, Serfaty L, Fourdan O, Levy VG, Poupon R: Improved survival after variceal bleeding in patients with cirrhosis over the past two decades. Hepatology 2004, 40:652-659.

45. Moreau R, Durand F, Poynard T, Duhamel C, Cervoni JP, Ichai P, Abergel A, Halimi C, Pauwels M, Bronowicki JP, Giostra E, Fleurot C, Gurnot D, Nouel O, Renard P, Rivoal M, Blanc P, Coumaros D, Ducloux S, Levy S, Pariente A, Perarnau JM, Roche J, Scribe-Outtas M, Valla D, Bernard B, Samuel D, Butel J, Hadengue A, Platek A, et al: Terlipressin in patients with cirrhosis and type 1 hepatorenal syndrome: a retrospective multicenter study. Gastroenterology 2002, 122:923-930.

46. Das V, Boelle PY, Galbois A, Guidet B, Maury E, Carbonell N, Moreau R, Offenstadt G: Cirrhotic patients in the medical intensive care unit: early prognosis and long-term survival. Crit Care Med 2010, 38:2108-2116.
47. Cholongitas E, Senzolo M, Patch D, Shaw S, Hui C, Burroughs AK: Review article: scoring systems for assessing prognosis in critically ill adult cirrhotics. Aliment Pharmacol Ther 2006, 24:453-464.

48. Soares M, Caruso P, Silva E, Teles JM, Lobo SM, Friedman G, Dal Pizzol F, Mello PV, Bozza FA, Silva UV, Torelly AP, Knibel MF, Rezende E, Netto JJ, Piras C, Castro A, Ferreira BS, Rea-Neto A, Olmedo PB, Salluh ال I: Characteristics and outcomes of patients with cancer requiring admission to intensive care units: a prospective multicenter study. Crit Care Med 2010, 38:9-15.

49. Huisman EJ, Trip EJ, Siersema PD, van Hoek B, van Erpecum KJ: Protein energy malnutrition predicts complications in liver cirrhosis. Eur J Gastroenterol Hepatol 2011, 23:982-989.

doi:10.1186/cc12687

Cite this article as: Sauneuf et al:: Increased survival of cirrhotic patients with septic shock. Critical Care 2013 17:R78.

\section{Submit your next manuscript to BioMed Central and take full advantage of:}

- Convenient online submission

- Thorough peer review

- No space constraints or color figure charges

- Immediate publication on acceptance

- Inclusion in PubMed, CAS, Scopus and Google Scholar

- Research which is freely available for redistribution

Submit your manuscript at www.biomedcentral.com/submit
Ciomed Central 